\title{
Analysis of the Determinants of Social Capital in Organizations
}

\section{María del Pilar Sandra Rosas Mercado}

$\mathrm{PhD}$ student, University Center for Economic and Managerial Sciences, University of Guadalajara, Mexico

\section{José G. Vargas-Hernández}

$\mathrm{PhD}$, Research Professor, University Center for Economic and Managerial Sciences, University of Guadalajara, Mexico

\begin{abstract}
At the present, Mexico is experiencing a climate of uncertainty and widespread distrust, due to the increase in the level of crime and low level of confidence derived from opportunistic behavior aimed at obtaining an individual rather than a collective benefit, affecting business activities in the country. This research analyzes the determinants of social capital in various theoretical and empirical investigations. The study proposes the analysis of eight dimensions necessary for the study of organizations. The methods employed are descriptive and explanatory research based on a research review and analysis of the determinants of social capital from a macroeconomic and microeconomic perspective. As a result of the review and analysis of the theoretical and empirical literature, this paper extends the model of determinants of social capital from six to eight to include trust and associations, from a point of view of interest groups. In addition to the above, it is considered vital to establish determinants of corporate governance, which promotes transparency and ethics in business, a fundamental pillar to increase the level of trust. The results of this research provide organizations with information on the determinants that must take care to increase their social capital and therefore their performance indicators in organizations. It is recommended that in order to promote substantial change in the country, the effort must be made jointly with the involving each organization or company, since it is difficult, if not impossible, for government institutions to do this in isolation. Change must be systemic, with the objective of increasing the level of social capital and collaborative work in the country to obtain better indicators of well-being.
\end{abstract}

Keywords: social capital, performance, collaborative work factors.

JEL Classification: D9, D21, G34, M14.

Cite as: Mercado, M.P.S.R., Vargas-Hernández, J.G. (2019). Analysis of the Determinants of Social Capital in Organizations. Business Ethics and Leadership, 3(1), 124-133. http://doi.org/10.21272/bel.3(1).124133.2019.

(C) The Authors, 2019. This article is published with open access at Sumy State University.

\section{Introduction}

In recent years, the global economy has experienced an economic crisis that has intensified in the countries of the world, over-indebtedness, financial and trade imbalances at a global level, impacting significantly on growth and employment rates. In addition, fraud, power management and social, corporate and governmental irresponsibility have been experienced, causing an impact on the indicators of well-being in the world. International organizations such as the World Bank, the International Monetary Fund (IMF), the Organization for Economic Co-operation and Development (OECD, 2004) and the Global Reporting Initiative (GRI, 2016) have been lobbying companies to develop better corporate governance practices, ethics and social responsibility towards sustainable development and impact.

According to various researches (Knack \& Keffer, 1997; Martinez et al., 2015; Femina, 2015; Oliveira, 2013), social capital is the basis for improving the performance of these practices. It is analyzed as an attribute of countries, communities, organizations, and individuals; since it is based on existing relationships between actors, where social organizations affect the functioning of economic activity, thus uniting the rational economic aspect of the individual with social systems (Coleman, 1998). One of the factors that govern relationships between individuals is the level of trust, which can range from the interpersonal, social, financial and institutional perspective; in addition to civic cooperation and associations (Gutiérrez and Ruiz, 2014).

Through multiple multidisciplinary investigations, social capital has been analyzed and evaluated in the world from a theoretical and empirical perspective in the last decades. It has proved to be an effective tool to promote 
development in the countries, as well as an instrument for the reduction of poverty rates, which increases the indicators of well-being in nations, organizations, and individuals (Mujika, Ayerbe, Ayerbe, Elola and Navarro, 2010). Accordingly, the World Bank, the OECD and the Economic Commission for Latin America and the Caribbean (ECLAC, 2005) promote an increase in the level of social capital in the countries in order to encourage the conditions of equality in income, as well as the reduction of poverty.

The factors or determinants most evaluated from the macroeconomic perspective in the literature of social capital are: trust, civic cooperation, and associations between individuals (Gutiérrez and Ruíz, 2014; Martínez Ayala, Aguayo, 2015). From the microeconomic point of view, the structure, relational and cognitive aspects of organizations have been analyzed (Nahapiel and Ghoshal, 1998).

At present, Mexico is experiencing a climate of uncertainty, insecurity and widespread distrust, due to the increase in the level of crime that has been unleashed in the main cities of the country, as well as a low level of confidence derived from opportunistic behaviors aimed at obtaining an individual benefit more than the collective, affecting welfare indicators in the country.

These facts, like others, have discouraged business and business activities, so that the productive apparatus has been affected, and therefore the levels of employment and growth. Individuals have been harmed by fraudulent practices and opportunistic behavior; which has given rise to a low level of confidence that affects their willingness to work collaboratively, presenting low levels of innovation and economic performance until the disintegration of their organizations.

For the above, the present research is descriptive, which will show the analysis of the determinants to incentivize social capital from a microeconomic perspective, so that they are taken into consideration to obtain better performance indicators; Also, the main theories that address the phenomenon under study will be presented.

\section{Background of the problem}

The Global Competitiveness Index generated by the World Economic Forum 2017-2018 (WEF, 2018), who evaluates, compares and determines a place for each country according to its level of competitiveness (total of 137 countries). It provides for the evaluation of twelve fundamental pillars, which are listed below: a) institutions b) infrastructure, c) macroeconomic environment, d) health and primary education, e) training and higher education, f) efficiency of good's market, g) efficiency in the labor market, h) development in the financial market, i) technological preparation, j) market size, k) sophistication in business, and finally 1) innovation.

The indicators that deserve greater attention are those of "institutions" where Mexico occupies the 123rd place, showing a significant backwardness in relation to the other countries. Next, we will show the aspects that present a greater problem, which were evaluated in the category of institutions (See Table 1).

Table 1. Main indicators evaluated in the "institutions" category in Mexico, the Global Competitiveness Index, Institutions evaluation in México 2017-2018

\begin{tabular}{|l|c|l|c|}
\hline \multicolumn{1}{|c|}{ Institution } & Place & \multicolumn{1}{c|}{ Institution } & Place \\
\hline Ethical conduct of firms & 117 & Efficiency in government spending & 121 \\
\hline Reliability of services by police & 134 & $\begin{array}{l}\text { Efficiency in the legal framework of dispute } \\
\text { resolution }\end{array}$ & 118 \\
\hline Business costs for terrorism & 87 & $\begin{array}{l}\text { Efficiency in the legal framework and challenge in } \\
\text { regulations }\end{array}$ & 87 \\
\hline Business costs for crime and violence & 131 & Favoritism in the decisions of government officials & 129 \\
\hline Organized crime & 134 & Judicial independence & 113 \\
\hline Property rights & 93 & Irregular payments and bribes & 105 \\
\hline
\end{tabular}

Source: Own elaboration with data of the Global Competitiveness Index (WEF, 2018)

The items to be addressed are ethical conduct of firms (location 117), business costs for crime and violence in place 131; organized crime (134), diversion of public funds (127), efficiency in government spending (121), favoritism in government decisions (129), efficiency in the legal framework for dispute resolution (118), among others. In addition to the above, the report shows that the main problems for business development are corruption, crime, and theft, government inefficiency and bureaucracy, access to financing, among others (See Figure 1). 
The most problematic factors for doing business in México

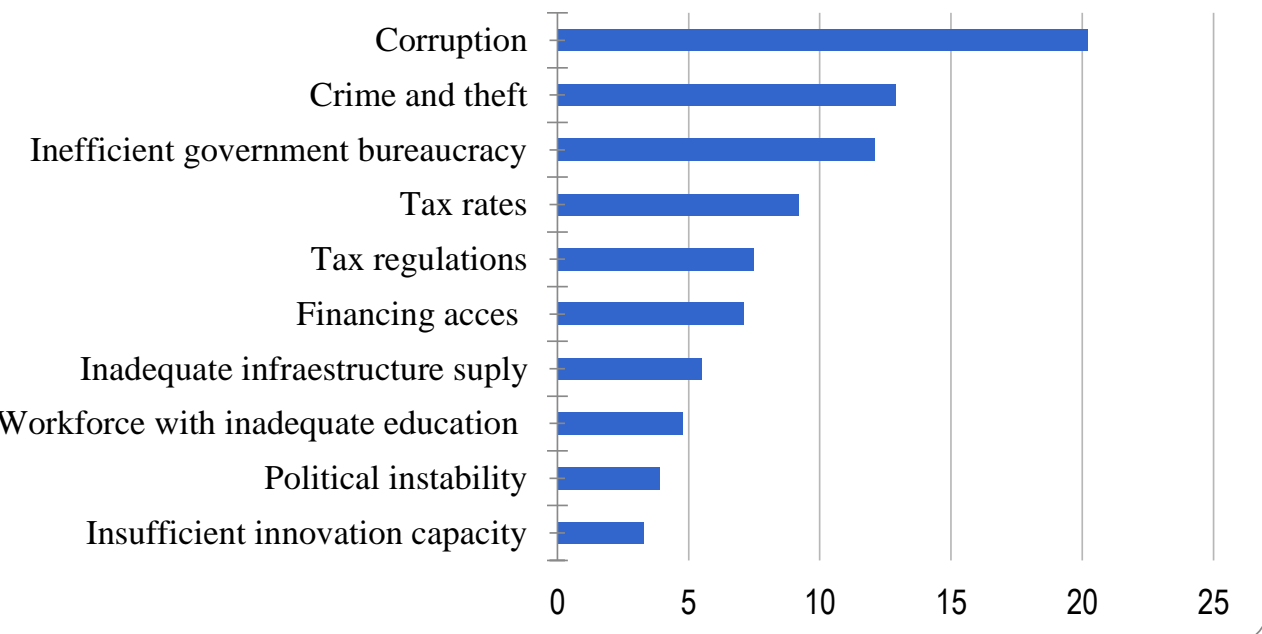

Figure 1. The most problematic factors for doing business in México

Source: World Economic Forum (2018)

Due to the prevailing environment in the country, it has been difficult to establish strong collaborative ties, which affects the organizations, cooperatives, or clusters in the country, since to date it has not been possible to create the scaffolding necessary to generate strong cooperation in the long term, affecting the expected benefits for which were also created. The loss of resources due to the large public and private investments that have been directed to these projects, derived from the poor linkage.

Some of the fundamental aspects that lead to this negative performance are the low level of trust between individuals and the lack of availability to work in teams through honest, transparent and responsible behavior towards the achievement of a common objective - social capital. Castañeda (1998) highlights the limited social capital existing in national companies as one of the main factors affecting their competitiveness. The lack of social trust in companies makes it difficult to establish long-term relationships among its participants, leading to a breakdown of the economic system, with a lack of community spirit. Capacity is restricted to certain economic bonds of trust, limiting development in the economy in general (idem).

The author emphasizes that a company with little social confidence accepts corrupt practices, political and economic inequality, besides being lacking in innovation; which discourages long-term investment from deteriorating productivity. Castañeda states that Mexicans do not have the capacity to individually carry out the profound changes that are indispensable to face the economic and social challenges of the country, while social capital is relatively scarce (Castañeda, 1998).

Another factor to be considered is the one proposed by the Economic Commission for Latin America and the Caribbean (ECLAC, 2018), which stresses that one of the main problems in Mexico is the inequality in household income; since even though poverty figures declined in 2016 from the previous year (45.7\% to $44.6 \%$ ), this is higher than the regional average, which is estimated to be at an average $30 \%$. Inequality is a major problem in the country, with $45 \%$ of the country's wealth being in the $20 \%$ of the population, this situation does not contribute to social cohesion in the country, generating a generalized feeling of distrust in the population. So far, the literature gap is that no research has been found to analyze the most relevant factors affecting social capital in organizations and clusters, and it is also necessary to analyze two more dimensions:

A. Trust and associations, with interest groups.

B. And corporate governance.

Once exposed, the objective of the research is established: Analyze the relevant determinants of social capital in various studies of a theoretical and empirical nature in order to contribute relevant information to the institutions.

\section{Theoretical-conceptual review}

At present, large corporations are made up of a large number of shareholders. The theory of the agency arises, having as protagonists "the agent and the principal", where the "principal" gives authority to "the agent" in 
order to efficiently manage organizations. Because shareholders have only a small shareholding, it is difficult for them to obtain complete information about the activities of managers, even though they may be detrimental to the principal's interests (Berle and Means, 1932; La Porta et al., Jensen and Meckling, 1976; Fama and Jensen, 1983; Rosas, 2006).

Due to the above, it is known that managers can generate opportunistic behaviors, pursuing their own objectives (Jensen and Meckling, 1976; Vishny and Shleifer, 1997; Rosas, 2006). Opportunism, as defined by Williamson (2007), is an effort to make a profit through dishonesty in negotiations. This can be in two ways: a) strategic concealment of information and b) not having the commitment of responsible behavior by the agent.

In any type of negotiation between two parties, an agent and principal relationship is established (Ayala, 1999), which is characterized by the existence of a hierarchical relationship, which can be established through a formal or informal contract. One of the parties has the possession of an active or administrative function of greater hierarchy, the main one; the other party administers the assets in a delegated way, which is called "agent". The fundamental feature in this relationship is the asymmetry of information; the agent has more information about the daily operation of the organization and the principal only has generic information, and therefore incurs high costs to monitor the agent's actions (Jensen and Meckling, 1976).

\section{A. The concept of social capital and corporate governance}

According to Castañeda, who refers to social capital as the ability of individuals to work and organize together to achieve a common goal. Trust among the members is obtained through a shared vision, leading to predictable, honest behaviors through cooperation (Castañeda, 1998). Francis Fukuyama (quoted by Castañeda, 1998: 26), states that "corporations and large corporations are built on trust", where it has countless cultural roots, that is, it develops in a society determined on the basis of how they perceive their different historical events. On the other hand, the OECD (2007) defines social capital as cohesion networks that share norms, values, and understandings that facilitate both internal and external cooperation in organizations.

Corporate governance is born as a response to the opportunist behavior of managers, in order to prevent possible fraud, power management and social irresponsibility for internal and external interest groups in organizations; corporate governance is the means by which companies are directed and controlled, prevailing ethical emphasis and social responsibility.

The objective of corporate governance is to maintain the balance of the interests of individuals, corporations, and society. The governance framework is in the efficient use of resources and the responsibility to manage them. From the financial point of view, Vishny and Shleifer (1997) determine that this one deals with the ways to assure the return of investment to the shareholders. The mission of modern corporations is to generate longterm benefits to increase shareholder value through transparency, fairness, and accountability, aligning the interests of shareholders with other stakeholders-groups of interest.

Two theories whose vision is contrary to agency theory and which support the philosophy of corporate governance are mentioned below; the theory of the Stakeholder Capitalism, which is based on the benefits that could be generated through the establishment of long-term relationships with all the actors involved, and Stewardship theory which describes the motivations and entrepreneurial behaviors and how they differ from the motivations opportunists as established by agency theory.

\section{B. Stakeholder Capitalism Theory and Stewardship Theory}

The theory of Stakeholder Capitalism is based on the freedom and voluntary action of interest groups. This stream has as its mission to maximize the corporate wealth that is obtained through the equal treatment of the partners and the interest groups mentioned.

According to Rotman (1999: 259) stakeholders "constitute all parties that are affected favorably or unfavorably by the operations of the company that carry risk and therefore gain or lose by the results of corporate activities". Some stakeholders are tied to corporations through explicit contracts like investors in capital markets or employees, while others through implicit contracts like clients. Freeman and Phillips (2002: 45) establishes the theory of Stakeholder Capitalism "... business is human institutions, where the creation of value is centered through cooperation among interest groups, who seek the balance of external forces for the understanding of business expectations and is based on the quest to do it in the best way".

In this approach, managers consider that the collective behaviors of individuals for the benefit of the organization will generate higher returns than those opportunists and individualists, which are considered 
ISSN (online) - 2520-6311; ISSN (print) - 2520-6761

appropriate mechanisms or structures of government that give authority and power to them (Donaldscon, Martínez, 2004).

The Stewardship theory is a completely opposite model to that established by the theory of agency. The model holds that the interests of managers are aligned with the interests of the principal, in contrast to the individualistic motivations that support the theory of the agency. According to this theory, managers seek the balance between the interests of shareholders and stakeholders, so they will try to make decisions for the benefit of all.

Davis, Schoorman, and Donaldson (1997) determine the behavioral characteristics of the steward, delimited by a proactive behavior identified with the organization, which allows him to define himself avoiding barriers that prevent him from completing his tasks, in addition to maintaining collectivist management. Due to the high need for growth and achievement, psychological motivations, the administrator appreciates the value of collaboration using his initiative to promote success through high participation and direct communication with subordinates, establishing with them links of trust. This one has a positive attitude towards the harmony of the groups avoiding conflict or confrontation.

The roots of this theory are found in Mc Gregor's (1994) "Y" theory and in Maslow's work (1970; Davis et al., 1997), in which man is characterized by the need for growth and achievement beyond its present state and is motivated by three psychological states: 1) experience gives meaning to work; 2) internal motivation; 3) the relationship between tasks and job characteristics. Stewardship theory states that motivated work results in high levels of performance and satisfaction, and it is important to note that control can be counterproductive because it limits its proactive behavior.

The authors make a comparison between the aforementioned assumptions and the assumptions of agency theory, with the aim of determining a framework of choice among individuals. On the other hand, the aspects that influence the organizations are the historical, political, cultural and economic factors that govern a society; as well as the levels of education, training, and domestic competence of the institutions that complement it (O'Shaughnessy, 1997).

Once the agent's and the principal's point of view are analyzed, one of the central aspects of the theory is the possible opportunism in the transactions carried out by the organizations and on the other hand those posed by the theory of Stakeholder Capitalism and the theory of Stewardship, where managers are oriented to achievement through internal motivation, are proactive and believe in a collectivist management, which shows a comparison between both in Table 2 .

Table 2. Comparison of Agency Theory and Stewardship Theory

\begin{tabular}{|c|c|c|}
\hline & Agency Theory & Stewardship Theory \\
\hline $\begin{array}{l}\text { Model of man } \\
\text { Behavior }\end{array}$ & $\begin{array}{l}\text { Economic man } \\
\text { Individual service }\end{array}$ & $\begin{array}{l}\text { Self-fulfillment individual } \\
\text { Collective service }\end{array}$ \\
\hline $\begin{array}{c}\text { Psychological Mechanisms } \\
\text { Motivations }\end{array}$ & $\begin{array}{l}\text { Low/economic need } \\
\text { Extrinsic }\end{array}$ & $\begin{array}{l}\text { High/need (growth, achievement, self- } \\
\text { realization). } \\
\text { Intrinsic }\end{array}$ \\
\hline $\begin{array}{l}\text { Social Comparison } \\
\text { Identification } \\
\text { Power }\end{array}$ & $\begin{array}{l}\text { Other managers } \\
\text { Low commitment value } \\
\text { Institutional (legitimate, coercive, reward) }\end{array}$ & $\begin{array}{l}\text { Principal } \\
\text { High commitment value } \\
\text { Staff (expert, referent). }\end{array}$ \\
\hline $\begin{array}{c}\text { Situational Mechanisms } \\
\text { Management Philosophy } \\
\text { Risk orientation } \\
\text { Framework in time } \\
\text { Goal } \\
\end{array}$ & $\begin{array}{l}\text { Control-oriented } \\
\text { Control mechanisms } \\
\text { Short term } \\
\text { Cost control }\end{array}$ & $\begin{array}{l}\text { Concern for involvement } \\
\text { Trust } \\
\text { Long term } \\
\text { Enhance your performance }\end{array}$ \\
\hline Cultural differences & $\begin{array}{l}\text { Individualism } \\
\text { High power distance }\end{array}$ & $\begin{array}{l}\text { Collectivism } \\
\text { Low distance power }\end{array}$ \\
\hline
\end{tabular}

Source: Davis et.al. (1997: 128)

\section{Review of the theoretical and empirical literature}

In a number of researches, it has been empirically demonstrated that there is a direct relationship between the level of social capital (trust) and economic performance indicators such as GDP per capita in the countries (Knack and Keffer, 1997). In addition, it has been demonstrated that benefits are obtained in cooperatives and communities applying the previously defined norms, networks and incentives, improving their performance in them (Martínez et al., 2015). 


\section{A. Analysis of the determinants of social capital: macroeconomic vision}

According to research by Martínez, et al. (2015), who evaluated the importance of social capital and trust in Mexico, through the analysis of the data provided by the Survey of Urban Social Capital (ENCAS), carried out by the Ministry of Social Development (SEDESOL) to the United Nations Development Program in Mexico (UNDP) in 2006 to 2,100 households in the country; who took the analysis of two variables, level of confidence perceived by individuals as well as credibility to the following instances: family, friends, neighbors, compadres, bosses, co-workers, teachers, businessmen, police, judges and government. The results of his research on the question of whether it is possible to trust people show that about $70 \%$ of the respondents say they have no confidence; already with the indicator constructed by them is reduced to $45 \%$, giving a more encouraging picture.

When analyzing the results of their econometric models (Probit ordered, using a maximum likelihood method), they show that older individuals living in the central region of the country have more confidence. Likewise, the determinants evaluated that have a positive impact on social capital are: Belonging to the northern region, some indigenous group, have a higher level of schooling and inhabit the northern region of the country. Indicators that negatively affect social capital are: female gender, south-southeast of the country, higher income and lack of social security.

The authors emphasize that trust is an intangible asset, which comes from the individual and will depend on the expected benefits of trusting others, trust decreases transaction costs, and organizations work better.

According to the statistical analysis developed by De La Torre et al. (2011), with data provided by the Urban Social Capital Survey (ENCAS), carried out by the Secretariat for Social Development (SEDESOL) in conjunction with the United Nations Development Program in Mexico (UNDP) in 2011, (5,400 interviews were carried out), where the results show that about $50.8 \%$ of the urban population determines that "the shoulders should be taken care of" and in rural areas $40.1 \%$. Likewise, $61.1 \%$ determine that there is less willingness to help, while in urban areas the percentage was $71 \%$. The reasons that determined not to do it are the economic situation, lack of communication and conflicts of religion (See Table 3).

Table 3. Determinants of social capital: macroeconomic vision

\begin{tabular}{|c|c|c|c|c|c|c|c|c|c|c|}
\hline $\begin{array}{l}\text { Macro- } \\
\text { economic } \\
\text { study }\end{array}$ & Sample & Year & & 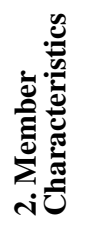 & 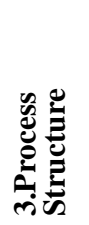 & 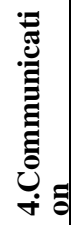 & 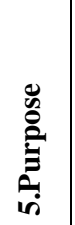 & 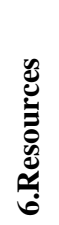 & 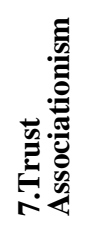 & 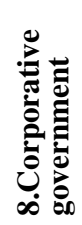 \\
\hline $\begin{array}{l}\text { Krack \& } \\
\text { Keffer, } 1997\end{array}$ & $\begin{array}{l}\text { They used reports from The World Values Survey } \\
1990-1991 \text { of } 29 \text { economy and GDP. }\end{array}$ & 1997 & & & & & & & $(+)$ & \\
\hline $\begin{array}{l}\text { Martínez et } \\
\text { al. (2015) }\end{array}$ & $\begin{array}{l}\text { They evaluated the importance of social capital and } \\
\text { trust in Mexico through the analysis of data from the } \\
\text { Urban Social Capital Survey (ENCAS) conducted } \\
\text { by the Social Development Secretariat (ISEDESOL) } \\
\text { jointly with the United Nations Development } \\
\text { Program in Mexico } \\
\text { (UNDP) in } 2006 \text { to } 2100 \text { households in the country. }\end{array}$ & 2006 & & & & & & & $(+)$ & \\
\hline $\begin{array}{l}\text { De la Torre, } \\
\text { R. \& López- } \\
\text { Rodríguez, } \\
\text { P. (2011) }\end{array}$ & $\begin{array}{l}\text { According to the statistical analysis developed with } \\
\text { data from the urban social capital survey (ENCAS) } \\
\text { developed by the Ministry of Social Development } \\
\text { (SEDESOL) in conjunction with the United Nations } \\
\text { Development Program of Mexico (UNDP) in 2011, } \\
5400 \text { surveys were conducted. }\end{array}$ & 2011 & & & & & & & $(+)$ & \\
\hline
\end{tabular}

Source: Own elaboration

\section{B. Analysis of the determinants of social capital: microeconomic vision}

Femina (2015) conducts research on social capital in organizations in both developing and developed countries, showing how social capital affects job satisfaction, as well as having a positive relationship in the performance of the workplace in the Kingdom United. In his research he used the European Survey on working conditions in the year 2010 (WERS pos); contrasting it with hospitals in Indonesia (developing country), through obtaining primary sources of research in Indonesia. The methodology used of structural equations of multilevel models. The results show a positive relationship in the United Kingdom, showing that a higher level of social capital, greater job satisfaction, and better financial performance; while in Indonesia it showed that higher social capital generates lower costs for hospital beds, while job satisfaction is not associated with performance variables as was thought. 
ISSN (online) - 2520-6311; ISSN (print) - 2520-6761

According to research by Oliveira (2013), who analyzes the influence of social capital and performance on the horizontal networks in the Rio Grande do Sul in Brazil (2010). Through a survey of 218 people from businesses belonging to 34 networks, it confirms that inter-organizational networks contribute to improving the performance of entrepreneurs by promoting the establishment of strong social capital bonds with positive results in the performance of organizations.

The author evaluates from the perspective of Nahapiet and Ghosal, (1998), which establish three dimensions: a) structure; b) relational (based on trust); and c) cognitive (share the meaning). The variables of performance evaluated were finance, clients, learning and innovation, and internal process. The findings of the study address that network managers can create mechanisms to foster social capital development and promoting cooperative ties to improve business performance in addition to the diversity of relationships and quality of the same have a positive influence on the results.

In relation to the research developed by Jiménez, Ponce, and Gutiérrez (2016), they developed an empirical model in order to show the social-entrepreneurial performance of social capital in 52 related companies in the metalworking industry in the municipality of Ciudad Juárez Chihuahua; this is measured by trust and reciprocity, and socio-business performance. The results show reduced levels in reciprocity. The method used is a multiple regression model (multivariate regression), where significant positive results were obtained in the relation between social capital and socio-business performance.

It is important to highlight that they developed a socio-business development index through 5 composite factors or sub-indices, which include productivity, technical and innovative skills of employees, social relations in the company, working conditions and human capital.

Research by Matessich, Murray, Monsey, and Wilder Research Center (2001), details twenty factors that must exist in the groups so that their collaboration is successful, and is considered relevant, which is the result of a literature review of 281 collaborative studies. It will be detailed below (see Table 4 below). After analyzing the information presented, it is concluded that have not been found an investigation that evaluates the eight dimensions for the analysis of social capital. So, it is proposed to take into consideration the eight dimensions proposed for analysis in organizations or clusters in the country, with the aim of strengthening and generating better indicators of sustainable management (see Table 4).

Table 4. Determinants of social capital: microeconomic vision

\begin{tabular}{|c|c|c|c|c|c|c|c|c|c|c|}
\hline $\begin{array}{l}\text { Macro-economic } \\
\text { study }\end{array}$ & Sample & Year & & 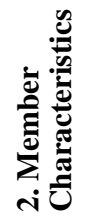 & 崖 & ¿ & . & 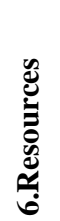 & 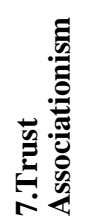 & 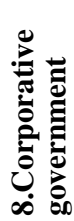 \\
\hline $\begin{array}{l}\text { Devi Femina }(2015) \\
\text { workplace social } \\
\text { capital,job satisfaction } \\
\text { and workplace } \\
\text { performance in } \\
\text { developed and } \\
\text { developing countries }\end{array}$ & $\begin{array}{l}\text { European Survey on Working } \\
\text { Conditions } 2010 \text { and the } 2011 \\
\text { Workplace Employment Relations } \\
\text { Study (WETS) in the United } \\
\text { Kingdom and obtaining } \\
\text { information from primary sources } \\
\text { to hospitals in Indonesia }\end{array}$ & $\begin{array}{l}2010 \\
- \\
2011\end{array}$ & & $(+)$ & $(+)$ & $(+)$ & $(+)$ & & $(+)$ & \\
\hline $\begin{array}{l}\text { Jimenez R. Ponce R. y } \\
\text { Gutiérerz Casas } \\
(2016) \text { B } \\
\text { Business performance } \\
\text { through social capital } \\
\text { and other } \\
\text { determinants. } \\
\text { PRETIUM Journal of } \\
\text { Economics, Finance } \\
\text { and Business 6(1), } 1-7 \\
\text { retrieved from } \\
\text { Academiajournals.co } \\
\text { m }\end{array}$ & $\begin{array}{l}\text { Empirical model in order to } \\
\text { demonstrate the socio-business } \\
\text { performance of social capital in } 52 \\
\text { companies related to the industrial } \\
\text { metal industry, social capital } \\
\text { established by trust and } \\
\text { reciprocity, and socio-business } \\
\text { performance, showing results in } \\
\text { reciprocity (2016) in the } \\
\text { municipality of Cd. Juárez. The } \\
\text { method is a multiple regression } \\
\text { model (multivariate regression) } \\
\text { positive results since the } \\
\text { relationship between social capital } \\
\text { and socio-business performance } \\
\text { was significant. }\end{array}$ & 2016 & & $(+)$ & $(+)$ & $(+)$ & & & $(+)$ & \\
\hline Mattesich et al. (2016) & Descriptive analysis of factors & 2000 & $\begin{array}{l}\text { Have not } \\
\text { been } \\
\text { proved } \\
\text { all the } \\
\text { factors }\end{array}$ & & & & & & & \\
\hline
\end{tabular}


The twenty factors proposed by Mattesich et al. (2001) are grouped into 7 dimensions: 1) environment; 2) characteristics of the members, 3) factors related to the process and the structure; 4) factors related to communication; 5) factors related to purpose; 6) resources and 7) trust and associations.

\section{Research methodology}

For the development of the present descriptive and explanatory research on the analysis of the determinants of social capital from a macroeconomic and microeconomic perspective, several theoretical and empirical investigations of determinants such as trust, reciprocity, and civic (macroeconomic) attitude were analyzed, and structure, relational aspect and (microeconomic) confidence, which show to be significant and consistent, so that we can assert that these determinants evaluate the phenomenon under study.

\section{Analysis of results}

Once analyzed the determinants of social capital, the present proposal is made in order that social capital is analyzed from eight dimensions in organizations; taking into consideration the elements proposed by Matessich et al (2001), who establish six dimensions: environment, characteristics of the members; process and structure, communication, purpose and resources, plus two more dimensions: trust and associations, from a point of view of interest groups. In addition to the above, it is considered vital to establish determinants of corporate governance, which promotes transparency and ethics in business, a fundamental pillar to increase the level of trust (see Table 5).

Table 5. Proposed determinants for the analysis of social capital in organizations

\begin{tabular}{|l|l|}
\hline \multirow{2}{*}{ 1. Environment } & A) History of collaboration \\
\hline \multirow{3}{*}{ 2. Characteristics of members } & B) Favorable political and social climate \\
\hline \multirow{5}{*}{ 3. Factors related to process and structure } & C) Mutual respect, understanding \\
\hline & D) Members see collaboration as something of their interest. \\
\hline & E) Ability to commit \\
\hline \multirow{3}{*}{ 4. Factors related to communication } & F) Multiple layers of participation \\
\hline \multirow{3}{*}{ 5. Factors related to purpose } & G) Development of clear roles and policy guidelines \\
\hline \multirow{2}{*}{ 6. Resources } & H) Adaptability \\
\hline & I) Rhythm and development of suitable objectives \\
\hline 7. Confidence and association & J) Open and efficient communication \\
\hline \multirow{3}{*}{ 8. Corporate governance } & K) Formal and informal relations \\
\hline & L) Objectives and achievable goals \\
\hline & M) Shared vision \\
\hline
\end{tabular}

Source: Own elaboration, with data provided by Mattesich, et. al. (2001) and various theories of corporate governance. Conceptual model.

\section{Conclusions and recommendations}

Throughout the present investigation, it is analyzed several theories representative of the object of study, social capital and the need to establish corporate governance in the institutions in the country. It has been shown the analysis of the determinants of social capital from a macro and microeconomic perspective, from an economic, rational, social and human vision in organizations. According to the analysis developed by international institutions such as ECLAC (2018) and the World Economic Forum (2018), which show no encouraging indicators of the situation in Mexico, inequality, crime, theft, and corruption prevail, among other variables that do not contribute to maintaining social cohesion and peace in the country; with repercussions on welfare and growth indicators.

The current situation is delicate, so the current research is developed in order to provide organizations with information on the determinants that must take care to increase their social capital and therefore their performance indicators in organizations. It is considered that in order for there to be a substantial change in the country, the effort must be made jointly, that is, in each organization or company, since it is difficult, if not impossible, for government institutions to do this in isolation, change must be systemic, with the objective of 
Business Ethics and Leadership, Volume 3, Issue 1, 2019

ISSN (online) - 2520-6311; ISSN (print) - 2520-6761

increasing the level of social capital and collaborative work in the country to obtain better indicators of wellbeing.

\section{References}

1. Ayala Espino, J. (1999). Instituciones y Economía: una Introducción al Neo institucionalismo Económico [Institutions and Economics: an Introduction to Neo-institutionalism Economic], México, Fondo de Cultura Económica [Economic Culture Fund], pp.155-164.

2. Berle, A. and Means, G. (1932). The Modern Corporation and Private Property, New York, Macmillan.

3. Castañeda, G. (1998). La Empresa Mexicana y su Gobierno Corporativo: Antecedentes y Desafios para el Siglo XXI, México, Universidad de Las Américas Puebla y Alter Ego Editores, pp. 441.

4. Comisión Económica para América Latina y el Caribe (CEPAL) [Economic Commission for Latin America and the Caribbean] (2018). Panorama Social de América Latina 2017[Social Panorama of Latin America 2017]. Santiago de Chile, Chile.

5. Comisión Económica para América Latina y el Caribe (CEPAL) [Economic Commission for Latin America and the Caribbean] (2005). Aprender de la Experiencia: el capital social en la superación de la pobreza [Learning from experience: social capital in overcoming poverty]. Santiago de Chile, Chile. Publicación de las Naciones Unidas [United Nations publication].

6. Coleman, J.S. (1988). Social capital in The Creation of Human Capital. American Journal of Sociology, 94, 95-121.

7. Davis, J., Schoorman, F. and Donaldson, L. (1997). Toward a Stewardship Theory of Management. Academy of Management Review, 22(1). https://doi.org/10.5465/amr.1997.9707180258.

8. De la Torre, R., Rodríguez, F., \& Sánchez, W. (2011). Propuesta: Análisis estadístico de los principales resultados de la Encuesta de Capital Social [Proposal: Statistical analysis of the main results of the Social Capital Survey]. XII Reunión Nacional de Investigación Demográfica En México [XII National Meeting of Demographic Research In Mexico]. Retrieved from http://somede.org/xireunion/memorias-electronicas/.

9. Fama, E. F., \& Jensen, M. C. (1983). Separation of Ownership and Control. Journal of Law and Economics, 26(2), 301-325. http://doi.org/10.1086/467037.

10.Femina, D. (2015). Workplace Social Capital, Job Satisfaction and Workplace Performance in Developed and Developing Countries (Tesis de pregrado doctoral) [Doctoral undergraduate thesis]. Universidad de Manchester, Manchester, Reino Unido [University of Manchester, Manchester, United Kingdom].

11.Freeman, R. Y., Phillips, R. (2002). Stakeholder Theory: A Libertarian Defense. Business Ethics Quarterly, $12(3), 49-62$.

12.Global Reportin Initiative (GRI) (2016). GRI 101: Fundamentos 2016. Amesterdam, GRI Standars.

13.Gutiérrez, M. Y., Ruíz, A. (2014). Capital social confianza y crecimiento económico una investigación para América Latina, Ciudad de México [Social capital confidence and economic growth a research for Latin America, Mexico City], México: Tecnológico de Monterrey [Monterrey Institute of Technology and Higher Education].

14.Jensen, C., and Meckling, W. (1976). Theory of the firm: Managerial behavior, agency costs and ownership structure. Journal of Financial Economics, 3(4), 305-360. http://doi.org/10.1016/0304-405X(76)90026-X.

15.Jiménez, R., Ponce, R. and Gutiérrez, L. (2016). El Desempeño Socioempresarial a través del Capital Social y otros Determinantes [Socio-enterprise Performance through Social Capital and other Determinants]. Pretium, Revista de Economía, Finanzas Y Negocios, 6(1), 1-7. Retrieved from Academiajournals.com.

16.Knack, K. and Keefer, P. (1997). Does Social Capital Have an Economic Payoff? A Cross-Country Investigation. Oxford University Press Stable URL: http://www.jstor.org/stable/2951271 Accessed : 05-03201620 : 18 UTC Your use of, 112(4), 1251-1288.

17.La Porta, R., López de Silanes, F., Shleifer, A. (1999). Corporate Ownership Around the World. The Journal Of Finance, 54(2), 471-517.

18.Matessich, Murray, Monsey \& Wilder Research Center (2001). Collaboration: What Makes it Work, Fieldstone Alliance.

19.Martínez, Almudena (2004). Estructura de Poder del Consejo de administración y Creación de Valor, XVIII Congreso Anual y XIV Congreso Hispano-Francés de AEDEM, 2004, España. [Power Structure of the Board of Directors and Value Creation, XVIII Annual Congress and XIV Hispano-French Congress of AEDEM, 2004, Spain].

20.Martínez et al. (2015). Confianza y capital social: evidencia para México [Trust and social capital: evidence for Mexico]. Economía, Sociedad $Y$ Territorio, xv, 35-59. Retrieved from http://apps.webofknowledge.com/full_record.do?product=UA\&search_mode=GeneralSearch\&qid=3\&SI $\mathrm{D}=1$ EwcHOW8ZufKPVWwUDb\&page $=1 \& \mathrm{doc}=3$. 
21.Maslow, A. (1970). Motivation and personality. New York. Harper and Row.

22.Mattessich, P., Murray-Close, M., \& Monsey, B. (2001). Collaboration: What Makes It Work, 2nd Edition: A Review of Research Literature on Factors Influencing Successful Collaboration. Publication http://doi.org/10.1016/S0022-3182(98)70349-8.

23.McGregor, D. (1994). El lado humano de las Empresas [The human side of business]. Santa Fé de Bogotá, Colombia: Mc Graw Hill Interamericana.

24.Mujika, A., Ayerbe, M., Ayerbe, O., Elola, A., \& Navarro, I. (2010). Manual para la autoevaluación del capital social en las organizaciones [Manual for the self-evaluation of social capital in organizations]. Bilbao. Deusto Publicaciones [Deusto Publishing].

25.Nahapiet, J., \& Ghoshal, S. (1998). Social Capital, Intellectual Capital, and the Organizational Advantage. The Academy of Management Review, 23(2), 242. http://doi.org/10.2307/259373.

26.OCDE (2004). White Paper on Corporate Governance in Latin America. Organización para la Cooperación $y$ El Desarrollo Económico OCDE (en línea): https://www.oecd.org/daf/ca/corporategovernanceprinciples/22368983.pdf.

27.OECD (2007).What is social capital. OECD Insights: Human Capital: How What You Know Shapes Your Life, 102-105. http://doi.org/10.1787/9789264029095-en.

28. Oliveira, J. F. (2013). The influence of the social capital on business performance: an analysis in the context of horizontal business networks. Revista de Administração Mackenzie, 14, 209-235. http://doi.org/10.1590/E-mail.

29.O'Shaughnessy, N. (1997).The idea of competitive advantage and the ideas of Michael Porter. Strategic Change, 6, 73-84. http://doi.org/10.1002/(SICI)1099-1697(199703)6:2<73::AID-JSC253>3.3.CO;2-K.

30.Pérez, R. (2003). La Gouvernance de l' enterprise [Corporate Governance], Francia, Ëditions La Découverte. pp. 112.

31.Rosas, M. (2006). Gobierno corporativo e impacto de la estructura de poder en la rentabilidad de las empresas que cotizan en la Bolsa Mexicana de Valores [Corporate governance and the impact of the power structure on the profitability of companies listed on the Mexican Stock Exchange]. Universidad de Guadalajara. Guadalajara, México.

32.Rotman (1999). Principles of Stakeholder Management. Bussines Ethics Quarterly, 12, 257-264.

33.Vishny, R. and Shleifer, A. (1997). A Survey of Corporate Governance, en. The Journal of Finance, 52(2) (Jun, 1997), 737-783.

34.Williamson, O. E. (2007). Transaction Cost Economics: An Introduction. Economics Discussion Paper, 033. http://doi.org/10.1017/CBO9781107415324.004.

35. World Economic Forum (WEF) (2018). Insigth Report: The Global Competitiveness Report. (K. Schwab, Ed.). 